\title{
Analysis of Rework Causes in Infrastructure Projects in Pulau Pinang
}

\author{
Nor Janna Tammy”, Isna Izzani Ismail, Raja Nor Husna Raja Mohd Noor, Juzailah Nur Yunus, \\ Zuraisah Dollah
}

School of Civil Engineering, College of Engineering, Universiti Teknologi MARA, Cawangan Pulau Pinang, 13500 Permatang Pauh, Pulau Pinang, Malaysia

Received January 29, 2021; Revised July 27, 2021; Accepted August 15, 2021

\section{Cite This Paper in the following Citation Styles}

(a): [1] Nor Janna Tammy, Isna Izzani Ismail, Raja Nor Husna Raja Mohd Noor, Juzailah Nur Yunus, Zuraisah Dollah, "Analyse of Rework Causes in Infrastructure Project in Pulau Pinang," Civil Engineering and Architecture, Vol. 9, No. 5A, pp. 145 - 156, 2021. DOI: 10.13189/cea.2021.091317.

(b): Nor Janna Tammy, Isna Izzani Ismail, Raja Nor Husna Raja Mohd Noor, Juzailah Nur Yunus, Zuraisah Dollah (2021). Analyse of Rework Causes in Infrastructure Project in Pulau Pinang. Civil Engineering and Architecture, 9(5A), 145 - 156. DOI: 10.13189/cea.2021.091317.

Copyright $\odot 2021$ by authors, all rights reserved. Authors agree that this article remains permanently open access under the terms of the Creative Commons Attribution License 4.0 International License

\begin{abstract}
Construction industry plays an important role in the Malaysia economy. One of the factors that contribute to this industry is infrastructure projects. Rework in infrastructure projects can cause the collapse of the Malaysian economy since it is detrimental to project outcomes. However, less attention was given regarding rework within the Malaysian construction industry especially in infrastructure projects. The purpose of this paper is to investigate the rework causes in the infrastructure project at Pulau Pinang. To acquire opinion of professionals from the construction industry about rework causes in infrastructure projects, questionnaires were distributed via Google form and received 52 responses. Data was analysed through SPSS 25.0 and ranked according to the level of importance. From this research, the results revealed that subcontractor factors and design related factors are the major categories that contribute to rework causes. In addition, the study showed that communication effectiveness within owners and changes made at request of the client are the main rework causes which considerably influenced infrastructure projects performance.
\end{abstract}

Keywords Rework, Infrastructure, Construction Project, Causes of Rework

\section{Introduction}

The construction industry plays a vital role in economic growth. It is an important industry and it contributes a substantial boost in overall Gross Domestic Product (GDP) of a country [1]. In construction and engineering projects, rework is a chronic problem [2], which means that the rework triggers future rework reduction mitigation approaches for building projects in Malaysia. In particular, rework harms projects triggering time and cost overruns. When the root causes of the rework were not given much attention, it tends to be a global phenomenon [3]. It has an adverse effect on performance of projects which contributes to the schedule overrun and expenditure in construction projects [4-6]. In the long term, the reputation of a construction company and its ability to attract new businesses can also be affected by rework. However, in Malaysia, there was not much research carried out on identifying rework causes especially in infrastructure projects and rework remains an innate problem as a result due to little being known about the background. Therefore, a list of rework causes in infrastructure projects need to be determined to reduce rework from previous studies. 


\section{Materials and Methods}

\subsection{Literature Review}

Through literature review, all causes regarding rework in infrastructure project that has been stated from previous studies were listed out. Rework will not occur without any reason, there must be some causes which contribute to rework. Most of the rework occurred due to design changes as per client request, unclear project management process, improper construction technology, and handling machinery and equipment. Nowadays, a systemic rework model has been developed to give a better explanation of the causes of rework so that solutions could be generated. A review of the literature indicates that finding the cause for reworks at construction sites has been the passion of many researchers over the world.

A better knowledge and a clear overview of the reworking structure can be provided through rework models. By the models, the character traits of rework and rework consideration can be determined. In this section, specific rework models were shown. Figure 1 shows the conceptual model of rework that was suggested by Love [7]. Based on this model, project management practices, organizational management practices, and project characteristics are the factors that directly and indirectly cause rework, and they were also divided into more particular elements which were productive and related to project performance.

This study conducted by $\mathrm{Ye}$ et al., [8] found some rework factors in other countries or regions as shown in
Table 1. A thorough literature review was first carried out by $\mathrm{Ye}$ et al., [8] to determine the preliminary list of rework causes and after conducting a semi structured interviews with 13 experts, an initial list of 47 rework causes were found.

Following consolidation, 39 causes of rework were identified according to its ranking based on mean value from questionnaire survey, as summarized in Table 2. Results gained from the questionnaire survey are that most causes have an average score of 3.0, which in the rating scale is considered significant. An uncertain and ambiguous project management process, poor building technology and the use of poor building materials, each with a mean value of over 3.70 , is most significant. The most significant factor is an uncertain and ambiguous project management process. Some activities are inadequately prepared to begin construction due to an urgent timetable or unreasonable decision-making involving client's ego or image issues. This results in much needless rework that could be avoided by the introduction of more sensible methods of project management. The standard of building technology plays a key role in building construction. Because the construction industry is still traditionally labour-intensive and makes little use of high technology, building quality is difficult to control, often resulting in considerable rework. Therefore, improving building technologies will help considerably in minimising rework. The poor quality of building materials is also a significant reason for rework.

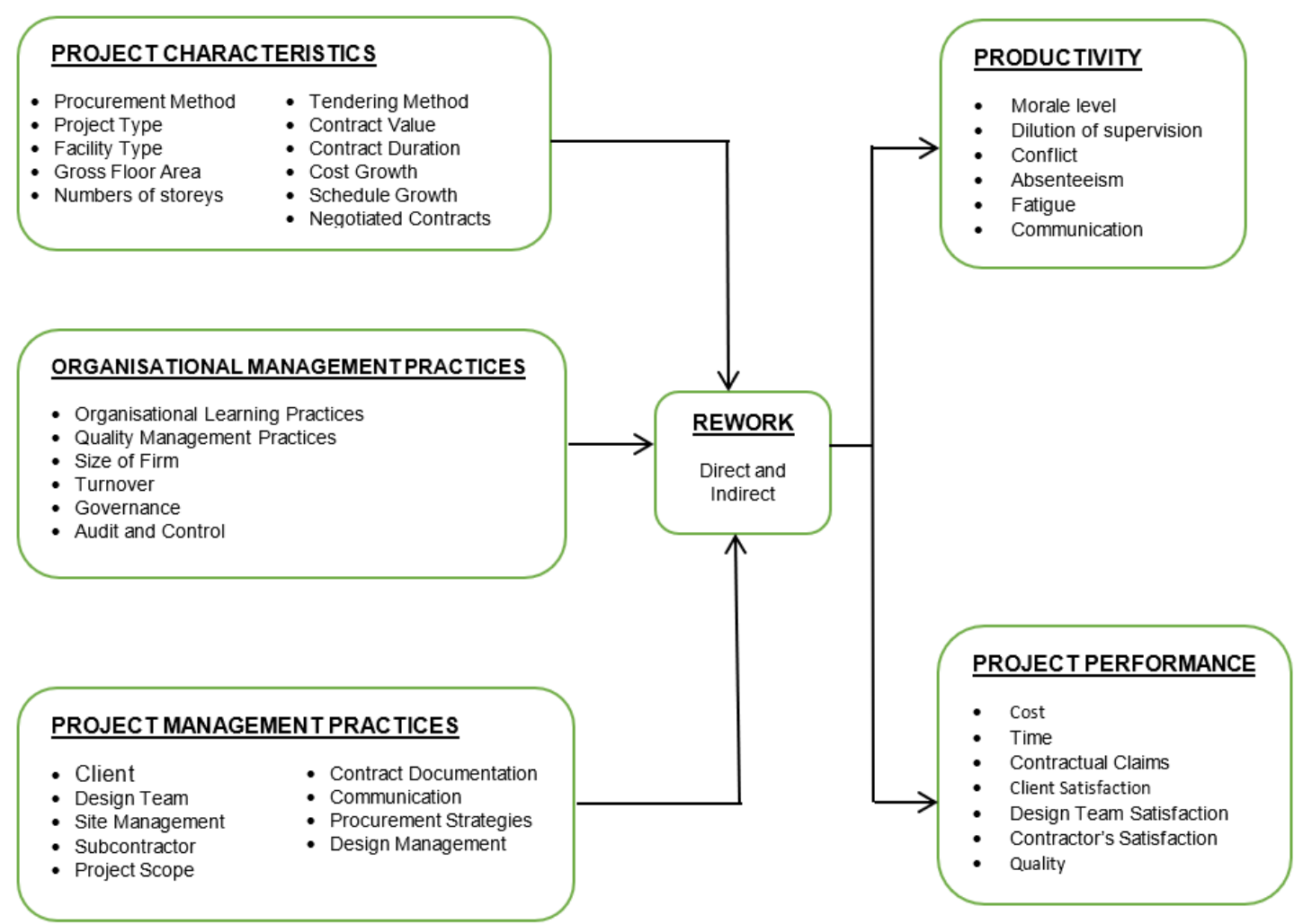

Figure 1. The Conceptual Model of Rework Notes/Sources: Love \& Edwards, (2004) 
Table 1. Rework Factors in Other Countries/Regions

\begin{tabular}{|c|c|c|c|c|c|c|c|}
\hline & China & Sweden & Canada & $\begin{array}{c}\text { United } \\
\text { Kingdom }\end{array}$ & Netherlands & Hong Kong & Australia \\
\hline $\begin{array}{c}\text { Rework } \\
\text { Cause }\end{array}$ & Current study & $\begin{array}{l}\text { Josephson } \\
\text { and } \\
\text { Hammarlund } \\
(1998) \\
\text { Josephson et } \\
\text { al. (2002) }\end{array}$ & $\begin{array}{l}\text { Favek et al. } \\
\quad(2003)\end{array}$ & $\begin{array}{l}\text { Hwang et al. } \\
\text { (2010) }\end{array}$ & $\begin{array}{l}\text { Mastenbrock } \\
\quad(2010)\end{array}$ & $\begin{array}{l}\text { Palaneeswaran } \\
\text { et al. (2008) }\end{array}$ & $\begin{array}{l}\text { Love et. Al } \\
\quad(2002)\end{array}$ \\
\hline $\mathrm{F} 1$ & Field management & $\mathrm{X}$ & $\mathrm{X}$ & - & $\mathrm{X}$ & $\mathrm{X}$ & $\mathrm{X}$ \\
\hline $\mathrm{F} 2$ & External environment & - & - & - & $\mathrm{X}$ & - & - \\
\hline F3 & Contract Management & - & - & - & - & - & - \\
\hline $\mathrm{F} 4$ & $\begin{array}{c}\text { Subcontractor } \\
\text { management }\end{array}$ & - & - & - & - & $\mathrm{X}$ & - \\
\hline F5 & Design management & $\mathrm{X}$ & - & $\mathrm{X}$ & - & $\mathrm{X}$ & $\mathrm{X}$ \\
\hline F6 & Project Communication & - & $\mathrm{X}$ & - & $\mathrm{X}$ & - & - \\
\hline F7 & Plan Changes & $\mathrm{x}$ & - & - & $\mathrm{X}$ & - & - \\
\hline F8 & Active rework & - & - & - & - & - & - \\
\hline F9 & Owner capability & $\mathrm{X}$ & - & $\mathrm{X}$ & - & $\mathrm{X}$ & $\mathrm{X}$ \\
\hline F10 & Scope management & - & - & - & - & - & - \\
\hline F11 & Process management & - & $\mathrm{X}$ & - & - & - & - \\
\hline
\end{tabular}

Table 2. Mean Score and Ranking of Causes of Rework

\begin{tabular}{|c|c|c|c|}
\hline $\begin{array}{l}\text { Overall } \\
\text { Ranking }\end{array}$ & Causes of rework in construction projects & Mean & $\begin{array}{l}\text { Standard } \\
\text { deviation }\end{array}$ \\
\hline 1 & Unclear of project process management & 3.834 & 1.275 \\
\hline 2 & Project scope change after work had been undertaken or completed & 3.794 & 0.999 \\
\hline 3 & Revisions and modifications of project function initiated by the owner & 3.729 & 1.095 \\
\hline 4 & Budget compression or escalation & 3.69 & 1.092 \\
\hline 5 & Schedule acceleration & 3.643 & 1.003 \\
\hline 6 & Replacement of materials/equipment during construction & 3.632 & 0.964 \\
\hline 7 & Inappropriate/contradictory project constructions initiated by manager & 3.617 & 1.049 \\
\hline $\mathrm{S}$ & Poor communication path of project instructions & 3.57 & 1.08 \\
\hline 9 & Poor communication/coordination between owner/end-user & 3.567 & 1.139 \\
\hline 10 & Delay in providing site conditions, such as water and electricity to the contractor & 3.495 & 1.079 \\
\hline 11 & Payment of low contract fees or delay in paying contract fees & 3.495 & 1.147 \\
\hline 12 & Ambiguity of items from contract documentation & 3.484 & 1.115 \\
\hline 13 & Lack of clear definition of contract documentation for working content & 3.44 & 0.997 \\
\hline 14 & Poor contract execution & 3.44 & 1.087 \\
\hline 15 & Active rework made by the contractors to improve quality & 3.415 & 1.112 \\
\hline 16 & Active rework made by the designers to improve quality & 3.365 & 1.06 \\
\hline 17 & $\begin{array}{c}\text { Lack of constructability because of separation between design achievements and construction } \\
\text { conditions }\end{array}$ & 3.361 & 1.158 \\
\hline 18 & Poor coordination of design team members & 3.357 & 0.996 \\
\hline 19 & Design error/omission because of too many design tasks and time boxing & 3.307 & 1.03 \\
\hline 20 & Poor quality of construction technology & 3.307 & 1.092 \\
\hline 21 & Use of poor construction materials & 3.249 & 1.173 \\
\hline 22 & Lack of use of advanced mechanical equipment & 3.209 & 1.07 \\
\hline 23 & Poor quality of construction procedure & 3.181 & 1.068 \\
\hline 24 & Ineffective use of construction management standard & 3.137 & 1.051 \\
\hline 25 & Construction errors caused by incomplete understanding of the intent of design & 3.13 & 1.122 \\
\hline 26 & Poor communication of construction managers & 3.123 & 1.222 \\
\hline 27 & Poor site conditions, such as water, electricity, and telephone & 3.116 & 1.05 \\
\hline 28 & Changes made by quite difficult construction methods & 3.112 & 1.138 \\
\hline 29 & Poor coordination of subcontractor between upstream and downstream & 3.076 & 1.188 \\
\hline 30 & Poor communication of construction team members & 3.022 & 1.116 \\
\hline 31 & Failure to provide protection to the completed works & 3.011 & 1.105 \\
\hline 32 & Poor supervision of admission materials/equipment & 3.004 & 1.124 \\
\hline 33 & New request made by the end-users to improve standards during construction & 2.993 & 1.06 \\
\hline 34 & New request made by the end-users during the final inspection and certification stage & 2.939 & 1.186 \\
\hline 35 & Adverse natural conditions, such as hot weather, rain, cold, earthquakes and floods & 2.935 & 1.088 \\
\hline 36 & Changes in government regulations, laws, and policy & 2.928 & 1.094 \\
\hline 37 & Shortage of construction materials/equipment in market & 2.91 & 1.134 \\
\hline 38 & Lack of strictly fulfilled for project process management & 2.892 & 1.187 \\
\hline 39 & Effect of social and cultural factors rework & 2.57 & 1.26 \\
\hline
\end{tabular}




\subsection{Methodology}

Factor analysis is a statistical technique to explain the difference between measured variables as a possible lower number of variables or factors that have not been measured. In this paper, the underlying classes of the 39 causes are discussed by factor analysis. 11 factors are produced by the principal component analysis (PCA). The final rotated part matrix is shown in Table 3. By combining the definitions of these variables with maximal cross-factor loads, each factor can be interpreted and named. This study discusses the situation of construction professionals and identifies 11 primary rework variables, comprising design management, communications management, field management, project scope management, project management, project process management, successful reworks, project plan adjustment, sub-contractor management, owner capacity [8].

From the studies, it is found that rework causes can be divided to client related factors [9-14], design-related factor [10-11, 14, 16-17], subcontractor [9-11, 18-19] and site management $[6,10-11,14,16,19]$. All listed causes were then used in the questionnaire survey in order to know the causes of rework in infrastructure project in Pulau Pinang. In order to assess mean value and standard deviation, SPSS 25.0 are used in ranking analysis. The data was classified specifically using mean value, standard deviation, overall mean and overall standard deviation for all the attributes for causes related to rework in infrastructure projects.

Table 3. Factor Profile in infrastructure project in Pulau Pinang

\begin{tabular}{|c|c|}
\hline & Details of the factors and causes reworks \\
\hline \multirow{6}{*}{ Factor 1: } & Management of contractor \\
\hline & Poor quality of construction technology and procedure \\
\hline & Lack of use of advanced mechanical equipment \\
\hline & Ineffective use of construction management standard \\
\hline & Construction errors \\
\hline & Use of poor construction materials \\
\hline \multirow{8}{*}{ Factor 2: } & Poor supervision of admission materials equipment \\
\hline & External environment \\
\hline & Poor site conditions \\
\hline & Change made by quite difficult construction methods \\
\hline & $\begin{array}{l}\text { New request from end-users to improve standards during construction or during final inspection and certification stage } \\
\text { Adverse natural conditions, e.g., extreme weather, earthquake, and floods }\end{array}$ \\
\hline & Changes in government regulations, laws, and policy \\
\hline & Shortage of construction materials/equipment in market \\
\hline & Effect of social and cultural factors \\
\hline \multirow{5}{*}{ Factor 3: } & Management of contract \\
\hline & Low contract fees or delay in payment \\
\hline & Ambiguity of items from the contract documentation \\
\hline & Lack of clear definition of contract documentation for working content \\
\hline & Poor contract execution \\
\hline \multirow{4}{*}{ Factor 4: } & Management of subcontractor \\
\hline & Poor communication of construction managers, team members and subcontractor \\
\hline & Failure to protect the completed works \\
\hline & Management of design \\
\hline \multirow{3}{*}{ Factor 5: } & Lack of design management because of separation between design and construction conditions \\
\hline & Poor coordination of design team members \\
\hline & Design error \\
\hline \multirow{4}{*}{ Factor 6: } & Management of communication \\
\hline & Inappropriate/contradictory project instructions initiated by managers \\
\hline & Poor communication path of project instructions \\
\hline & Changes of project plan \\
\hline \multirow{3}{*}{ Factor 7: } & Compression to increasing the budget \\
\hline & Accelerating time to shortening the schedule \\
\hline & Replacement of materials/equipment during construction \\
\hline \multirow{3}{*}{ Factor 8: } & Changes in quality improvement \\
\hline & Changes made by the designers or contractor to improve quality \\
\hline & Management of client \\
\hline \multirow[t]{3}{*}{ Factor 9: } & Poor communication/coordination between owner and end-users \\
\hline & Delay in providing the site conditions, such as water and electricity, to the contractor \\
\hline & Management of project scope \\
\hline \multirow{3}{*}{ Factor 10: } & Project scope was changed after work had been undertaken/completed \\
\hline & Revisions and modifications of the project function initiated by the owner/end-user \\
\hline & Management of project process \\
\hline \multirow[t]{2}{*}{ Factor 11: } & Unclear of project process management \\
\hline & Lack of strictly fulfilled for project process management \\
\hline
\end{tabular}




\subsubsection{Questionnaire survey}

Question survey was adopted in this research as the quantitative method to identify the main causes of rework in infrastructure projects. This questionnaire survey was found to be effective because of the relative case of obtaining standard data appropriate to achieve the objectives. To identify rework causes, surveys were conducted within 6 categories of companies related to construction industries especially in infrastructure projects. They were from Architecture firms, Consulting Engineers, Project Management firms, Contractor and sub-contractors, also from others firms including developers and surveyors. All those companies were selected based on their previous project performance especially in infrastructure surrounding Pulau Pinang. The questionnaires were sent via Google form through an e-mail and at the end of the questionnaire survey period, data had been collected from 52 respondents.

The finalized questionnaire contains 2 parts. The first part was intended to gather the company category, respondents job position in that company and work experience. Last part involves the rating of 4 categories of rework causes which are client related factor, design related factors, site management and subcontractor. Each category consists of a list or rework causes giving a total of 32 causes overall. A five-point Likert scale $(1=$ strongly disagree, $2=$ disagree, $3=$ uncertain, $4=$ agree, 5 $=$ strongly agree) was adopted in order to analyse the importance of each cause [8, 20-21]

\section{Result and Discussion}

\subsection{Descriptive Statistics}

The respondents completing the questionnaire were from different companies: Architect (4\%), Consulting Engineer (26\%), Project Manager (46\%), Contractor $(15 \%)$, and Other, including developer and surveyor (9\%). However, Quantity Surveyors were not involved in answering this questionnaire. The percentage of company categories involved with this questionnaire were presented in Figure 2(a) and the job position of respondents in each company are shown in Figure 2(b). The majority of respondents were construction officers (including civil engineers, safety directors etc.) with $46.15 \%$, followed by construction managers (including project manager, superintended officers, resident engineers etc.) with $25 \%$. However, Figure 3 shows the working experience of all the respondents in the company. $71.15 \%$ of the respondents have experience of more than 10 years in the construction industry.

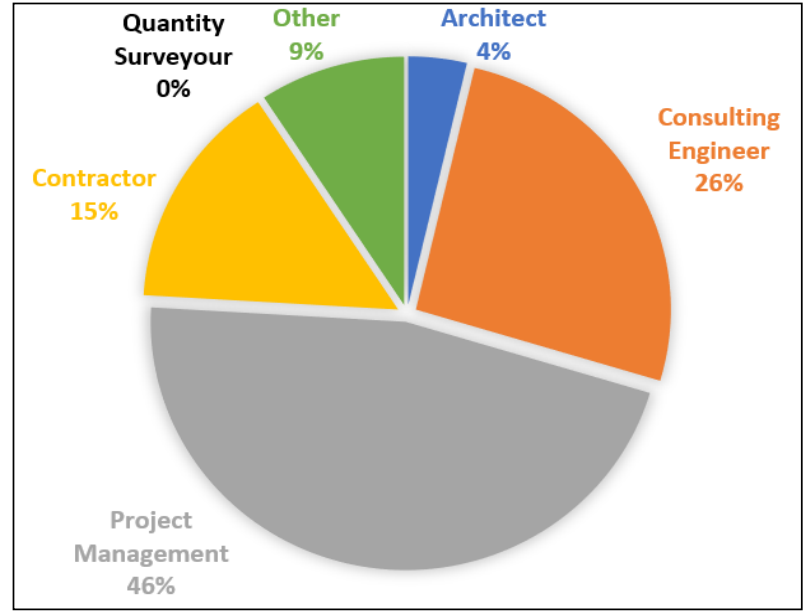

Figure 2(a). Company category of respondents in infrastructure projects

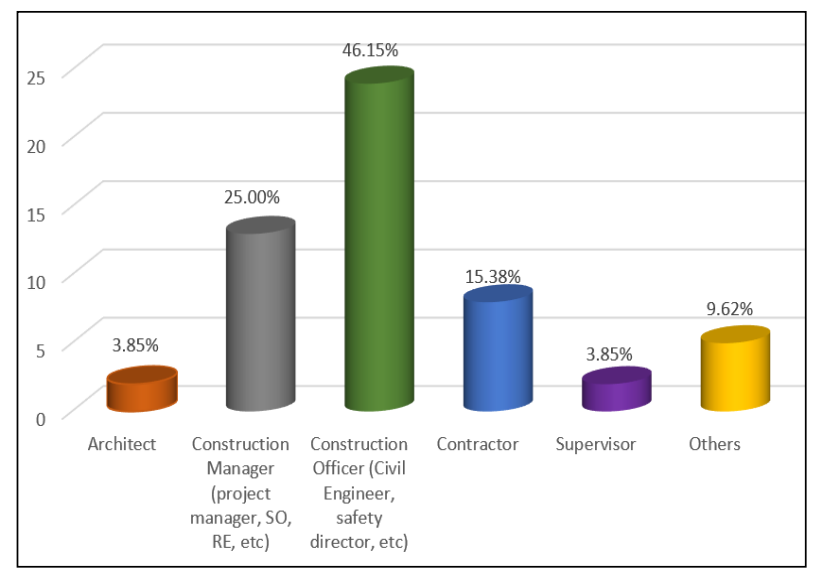

Figure 2(b). Job position of respondents in infrastructure projects

The respondents were mostly construction officers and construction managers with work experience of more than 10 years, competent with infrastructure projects and have qualified knowledge related to engineering. Therefore, it can help produce more reliable results towards the finding of the research study since the majority of respondents are very well versed about rework in infrastructure projects.

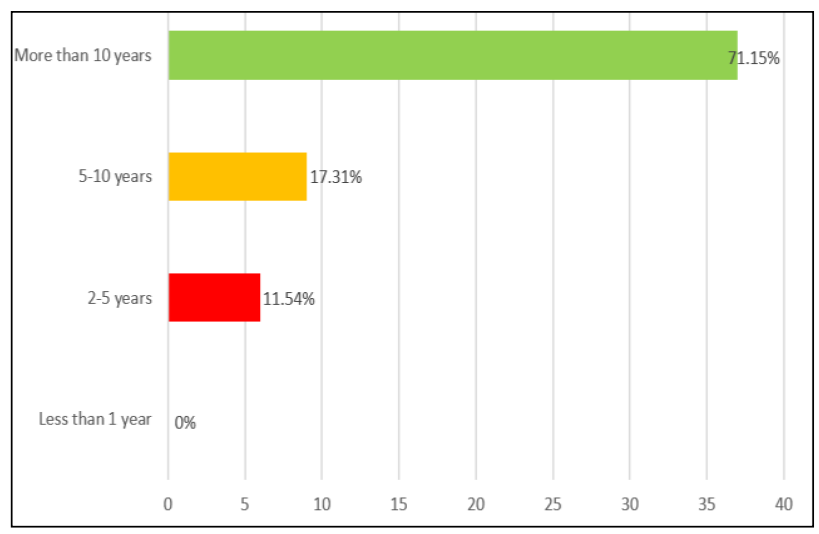

Figure 3. Work Experience of Respondents in Infrastructure Projects 


\subsection{Causes of Rework in Infrastructure Projects}

Literature analysis has been used to determine the key causes of reworking in infrastructure programs. From the literature review, it is found that four classes can be grouped into the triggers of rework in the infrastructure project, which were: client-related factor, design-related factor, site management and subcontractor. In the infrastructure project, ranking analysis by mean, standard deviation and Relative Importance Index (RII) are used to classify the key causes attributes of rework causes. In ranking analysis, scales from rank 1 to 5 are used to denote the attributes of rework in infrastructure projects that are most important to the least critical key causes.

\subsubsection{Client-related factors}

The results ranking of the client related rework triggers group in the infrastructure project are shown in Table 4. Most respondents believe that communication efficiency among owners is the most important cause of client related factor rework attributes in the infrastructure project and has the highest RII value of $77.31 \%$. Lack of communication between client and design team may contribute to documentation errors. Simpeh [10] stressed that client together with members of the project team shall collaborate in order for the project to be carried on or ahead of production time. In management practice, good communication and congruent cooperation are a shared point of view for successful project execution and key to alleviating documentation errors and omissions. [20].
Next, change in plans or scope is the second cause of rework for client related in infrastructure projects with RII value of $74.62 \%$. This is due to the owners or client may not have a clear opinion on the project structure and appearance of the project before authorizing it. Inadequate organisation among client, owners and end-user is the third ranking for rework causes due to client related factors with RII value of $73.85 \%$.

\subsubsection{Design-related factors}

As for the design-related rework causes, factors in the infrastructure project are shown in Table 5. Most respondents accept that changes made by the client's request are the key causes leading to the rework of $77.31 \%$ of the highest RII value for design-related factors in the infrastructure project. Ekambaram [12] stated that design and construction related factors are client-based rework symptoms such as client request for design changes and construction related changes insisted by clients.

The second ranking of rework causes contribute to design related would be design consistency with RII value of $73.85 \%$ because there was no consistency in the design with the original demand of the project.

Insufficient time for design stage would be the third rank of rework causes for design related in infrastructure project with RII value of $73.08 \%$. This includes incomplete design at the time of the tender as well as insufficient time to prepare contract documentation. 
Table 4. RII and Rank of Rework Causes for Client-related Factors in Infrastructure Projects

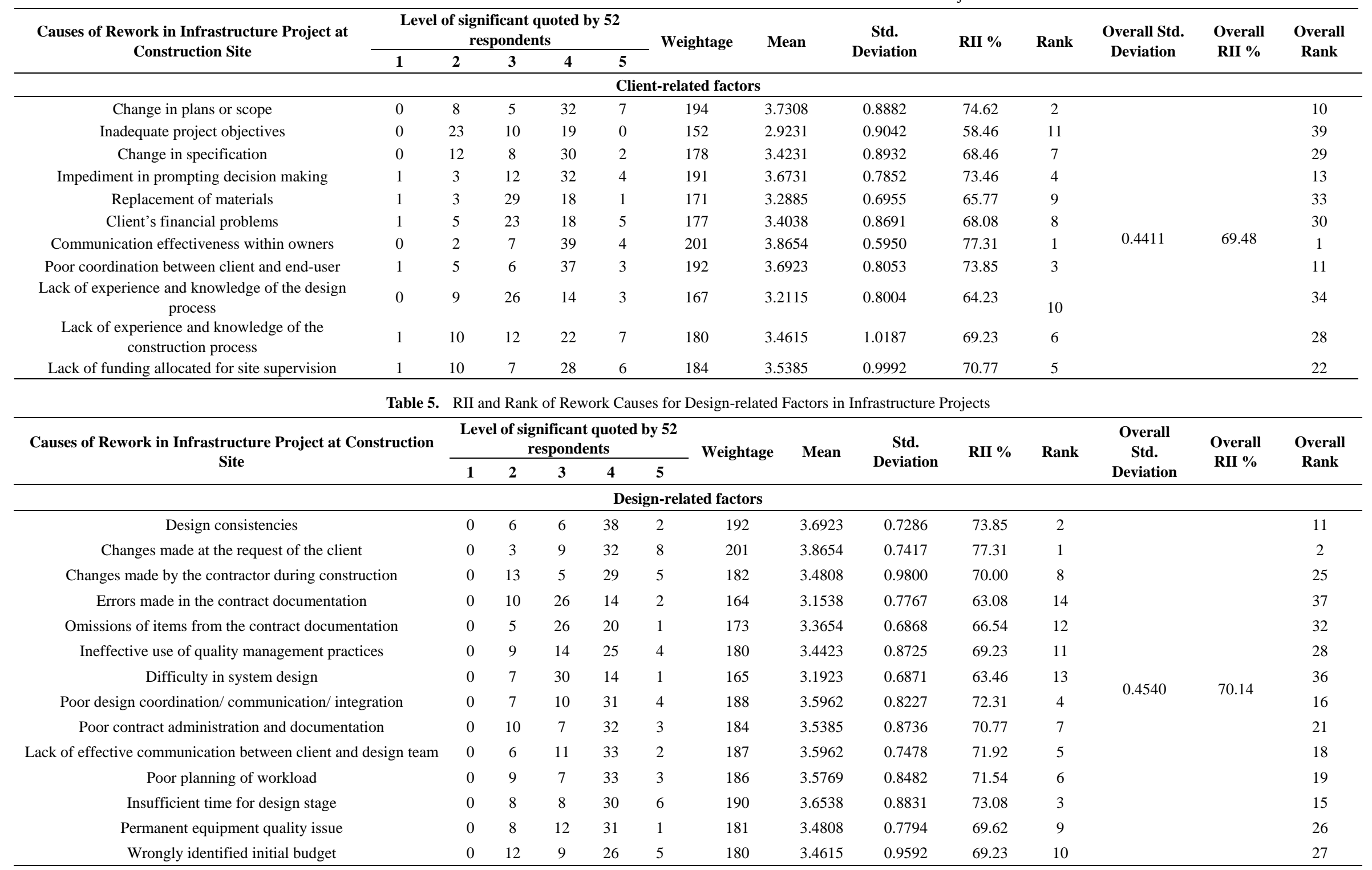


Table 6. RII and Rank of Rework Causes for Site Management Factors in Infrastructure Projects

\begin{tabular}{|c|c|c|c|c|c|c|c|c|c|c|c|c|c|}
\hline \multirow{2}{*}{$\begin{array}{c}\text { Causes of } \\
\text { Rework in } \\
\text { Infrastructure } \\
\text { Project at } \\
\text { Construction } \\
\text { Site } \\
\end{array}$} & \multicolumn{5}{|c|}{$\begin{array}{c}\text { Level of significant } \\
\text { quoted by } 52 \\
\text { respondents } \\
\end{array}$} & \multirow{2}{*}{ Weightage } & \multirow{2}{*}{ Mean } & \multirow{2}{*}{$\begin{array}{c}\text { Std. } \\
\text { Deviation }\end{array}$} & \multirow{2}{*}{ RII \% } & \multirow{2}{*}{ Rank } & \multirow{2}{*}{$\begin{array}{c}\text { Overall } \\
\text { Std. } \\
\text { Deviation }\end{array}$} & \multirow{2}{*}{$\begin{array}{l}\text { Overall } \\
\text { RII \% }\end{array}$} & \multirow{2}{*}{$\begin{array}{c}\text { Overall } \\
\text { Rank }\end{array}$} \\
\hline & 1 & 2 & 3 & 4 & 5 & & & & & & & & \\
\hline \multicolumn{14}{|c|}{ Site Management } \\
\hline $\begin{array}{c}\text { Ineffective use } \\
\text { of quality } \\
\text { management } \\
\text { practices }\end{array}$ & 0 & 9 & 6 & 37 & 0 & 184 & 3.5385 & 0.7787 & 70.77 & 4 & & & 20 \\
\hline $\begin{array}{l}\text { Lack of training } \\
\text { and experience }\end{array}$ & 0 & 7 & 14 & 27 & 4 & 184 & 3.5385 & 0.8275 & 70.77 & 6 & & & 24 \\
\hline $\begin{array}{l}\text { Setting-out } \\
\text { errors }\end{array}$ & 0 & 10 & 25 & 14 & 3 & 166 & 3.1923 & 0.8174 & 63.85 & 8 & & & 35 \\
\hline $\begin{array}{l}\text { Constructability } \\
\text { problems }\end{array}$ & 0 & 6 & 4 & 39 & 3 & 195 & 3.7500 & 0.7376 & 75.00 & 1 & & & 8 \\
\hline $\begin{array}{c}\text { Poor planning } \\
\text { of resources }\end{array}$ & 2 & 4 & 14 & 24 & 8 & 188 & 3.5962 & 0.9754 & 72.31 & 3 & & & 17 \\
\hline $\begin{array}{l}\text { Poor } \\
\text { coordination of } \\
\text { resources (e.g. } \\
\text { Subcontractor) }\end{array}$ & 1 & 3 & 13 & 29 & 6 & 192 & 3.7115 & 0.8245 & 73.85 & 2 & 0.5871 & 69.70 & 12 \\
\hline $\begin{array}{l}\text { Failure to } \\
\text { provide } \\
\text { protection to } \\
\text { constructed } \\
\text { works }\end{array}$ & 1 & 6 & 23 & 15 & 7 & 177 & 3.3846 & 0.9321 & 68.08 & 7 & & & 31 \\
\hline Lack of safety & 1 & 6 & 13 & 28 & 4 & 184 & 3.5385 & 0.8736 & 70.77 & 5 & & & 23 \\
\hline $\begin{array}{c}\text { Excessive } \\
\text { overtime }\end{array}$ & 0 & 10 & 30 & 9 & 3 & 161 & 3.0962 & 0.7736 & 61.92 & 9 & & & 38 \\
\hline
\end{tabular}

\subsubsection{Site management factors}

Love et al. [7] stated that in order to plan the work that need to be done, site management team must work with subcontractors. Table 3 indicates the result ranking for site management factors of rework cause in infrastructure project. From the table, constructability problem is the main cause of rework for site management factors with RII value of $75 \%$. Poor coordination of resources in example subcontractors come in second ranking with RII value of $73.85 \%$ and the third ranking is poor planning of resources with RII value of $72.31 \%$. As for the fourth, fifth and sixth ranking, we can see that the RII value were the same which is $70.77 \%$. According to Vilasini, Gamage, Kahangamage, \& N [22] if equal relative importance indices of the individual factors obtain it will be ranked according to the percentage of respondents scoring 4 or more. Due to that, even though all causes have same RII value the percentage of respondents scoring 4 or more is what makes the ranking different. Constructability problems are the fourth ranking for rework causes in site management factor. Setting out errors is the first rank with the highest mean value followed by lack of skills and expertise and weak management of resources as most important rework causes for site supervision factor in South Africa [10]

\subsubsection{Subcontractor factors}

Subcontractor related factors were scrutinized and Table 7 reveals the findings. After ranking the RII value of the responses, shortage of skilled supervisors was rated as most predominant rework causes for subcontractor factor in infrastructure projects with RII value $76.54 \%$ subsequently unclear instruction to workers on second ranking, inadequate supervisors, foreman or tradesmen ratios on third-ranking and defective workmanship on the fourth-ranking. All three factors had the same RII value which is $75.77 \%$ but with different percentages of respondents scoring 4 or more.

Comparing the data result with a study conducted by Simpeh [10], non-compliance with the specification is the predominant rework causes for subcontractor factor followed by poor workers level of expertise, lack of trained workers and shortage of skilled supervisors and defective workmanship. Simpeh [10] also points out that factors attributable to the construction-related source of rework cost are damages caused by a subcontractor.

However, a study conducted by Trach et al. [13] stated that excessive workload and market conditions are external factors that contribute to the level of rework in the construction project. Restrictions on access for eligible skilled and knowledgeable subcontractors and employees cause increased defects and poor workmanship. 
Table 7. RII and Rank of Rework Causes for Subcontractor Factors in Infrastructure Projects

\begin{tabular}{|c|c|c|c|c|c|c|c|c|c|c|c|c|c|}
\hline \multirow{2}{*}{$\begin{array}{l}\text { Causes of Rework in Infrastructure } \\
\text { Project at Construction Site }\end{array}$} & \multicolumn{5}{|c|}{ Level of significant quoted by 52 respondents } & \multirow{2}{*}{ Weightage } & \multirow{2}{*}{ Mean } & \multirow{2}{*}{$\begin{array}{l}\text { Std. } \\
\text { Deviation }\end{array}$} & \multirow{2}{*}{ RII \% } & \multirow{2}{*}{ Rank } & \multirow{2}{*}{$\begin{array}{l}\text { Overall Std. } \\
\text { Deviation }\end{array}$} & \multirow{2}{*}{$\begin{array}{l}\text { Overall } \\
\text { RII \% }\end{array}$} & \multirow{2}{*}{$\begin{array}{c}\text { Overall } \\
\text { Rank }\end{array}$} \\
\hline & $\mathbf{1}$ & 2 & 3 & 4 & 5 & & & & & & & & \\
\hline \multicolumn{14}{|c|}{ Subcontractor } \\
\hline Unclear instruction to workers & 0 & 3 & 9 & 36 & 4 & 197 & 3.7885 & 0.6668 & 75.77 & 2 & & & 4 \\
\hline Non-compliance with specification & 0 & 6 & 7 & 33 & 6 & 195 & 3.7115 & 0.8480 & 75.00 & 6 & & & 9 \\
\hline Shortage of skilled supervisors & 1 & 3 & 7 & 34 & 7 & 199 & 3.8269 & 0.8098 & 76.54 & 1 & & & 3 \\
\hline Shortage of skilled labour & 1 & 4 & 12 & 28 & 7 & 192 & 3.6538 & 0.9050 & 73.85 & 7 & & & 12 \\
\hline Low labour skill level & 0 & 4 & 13 & 26 & 9 & 196 & 3.7308 & 0.8658 & 75.38 & 5 & 0.6465 & 75.14 & 7 \\
\hline $\begin{array}{c}\text { Inadequate } \\
\text { Supervisor/Foreman/Tradesmen ratios }\end{array}$ & 0 & 3 & 12 & 30 & 7 & 197 & 3.7500 & 0.7890 & 75.77 & 3 & & & 5 \\
\hline Defective workmanship & 0 & 2 & 15 & 27 & 8 & 197 & 3.7885 & 0.7498 & 75.77 & 4 & & & 6 \\
\hline $\begin{array}{l}\text { Damage to other trades work due to } \\
\text { carelessness }\end{array}$ & 0 & 7 & 7 & 35 & 3 & 190 & 3.6154 & 0.8202 & 73.08 & 8 & & & 14 \\
\hline
\end{tabular}




\subsubsection{Rework causes category in infrastructure projects}

Determination of rework causes analysis was performed using SPSS 25.0 through mean, standard deviation and Relative Importance Index (RII). Based on the analysis in Table 8 , it is shown that the ranking of each rework causes category and it is found that subcontractor factor was ranked first with highest RII 75.14\%. That reflects that the involvement of subcontractors is important in reducing rework in infrastructure projects. This result is in line with study conducted by Love and Edwards [7], Simpeh [10], Enshassi et al. [14] and Palaneeswaran [15]. Design-related factors was ranked second with RII (10.14\%) followed by site management with RII (69.70\%) and lastly client-related factors with RII (69.48\%).

Table 8. RII and ranks of rework causes category in infrastructure project at construction site.

\begin{tabular}{cccc}
\hline Rework causes category & RII\% & SD & Rank \\
\hline Subcontractor & 75.14 & 0.65 & 1st \\
Design-related factors & 70.14 & 0.45 & 2nd \\
Site Management & 69.70 & 0.59 & 3rd \\
Client-related factors & 69.48 & 0.44 & 4th \\
\hline
\end{tabular}

\subsubsection{Top ten rework causes in infrastructure projects}

Table 9 shows ten most important causes that contribute to rework in infrastructure project. The first rank goes to communication effectiveness between owner with RII $77.31 \%$ and total respondents scoring more or equal than four $(\geq 4)$ and five (5) are 43 . That was how the ranking using RII was obtained. Communication effectiveness causes is commensurate with the study conducted by Ye et al. [8], Muwafaq et al. [9], Palaneeswaran [15], Wilson et al. [22] and Ghannadpour et al. [23]. They stated that poor communication is an important cause of rework for client related factors. This cause may occur due to the owners who are rarely involved in any project meetings, which does not put an effort into knowing any project matters or due to rules and regulations in decision making and project management. It leads to late design changes, modifications to requirements, product adjustments and adjustments in project management plan, all of which led to rework. Communication barriers between clients and other developers could also result in conflicts and misunderstandings between stakeholders on the requirements for contract documentation. Thus, it affects the process negatively. The findings therefore show the importance of growing cooperation among the contracting parties to ensure a team working environment and a working atmosphere in which everyone involved in the projects meet their targets.

However, the second rank goes to changes made at the request of the client also with RII $77.31 \%$ but with total respondents scoring more or equal than four $(\geq 4)$ and five (5) are 40.

According to Vilasini et al. [24] of equal relative importance are the indices of the individual factors obtained and it will be ranked according to the percentage of respondents scoring 4 or more [24]. Changes made at the request of the client is compatible with the study conducted by Wilson et al. [22], Hwang and Yang [20] and Muwafaq et al. [9], which states that design changes made by client is on the top five of rework causes in design related factors. There were 6 causes from subcontractor category in the list of 10 most important rework causes which also indicate why subcontractor category is the first rank of rework causes.

Table 9. RII and rank of 10 most important rework causes in infrastructure project at construction site

\begin{tabular}{|c|c|c|c|c|c|c|c|c|c|}
\hline \multirow{2}{*}{$\begin{array}{l}\text { Causes of Rework in } \\
\text { Infrastructure Project at } \\
\text { Construction Site }\end{array}$} & \multirow{2}{*}{$\begin{array}{l}\text { Rework } \\
\text { category }\end{array}$} & \multicolumn{5}{|c|}{$\begin{array}{c}\text { Level of significant quoted by } 52 \\
\text { respondents }\end{array}$} & \multirow{2}{*}{ Weightage } & \multirow{2}{*}{ RII \% } & \multirow{2}{*}{ Rank } \\
\hline & & 1 & 2 & 3 & 4 & 5 & & & \\
\hline $\begin{array}{c}\text { Communication effectiveness } \\
\text { within owners }\end{array}$ & client-related & 0 & 2 & 7 & 39 & 4 & 201 & 77.31 & 1 \\
\hline $\begin{array}{c}\text { Changes made at the request of the } \\
\text { client }\end{array}$ & design-related & 0 & 3 & 9 & 32 & 8 & 201 & 77.31 & 2 \\
\hline Shortage of skilled supervisors & sub-contractor & 1 & 3 & 7 & 34 & 7 & 199 & 76.54 & 3 \\
\hline Unclear instruction to workers & sub-contractor & 0 & 3 & 9 & 36 & 4 & 197 & 75.77 & 4 \\
\hline $\begin{array}{c}\text { Inadequate Supervisor/Foreman/ } \\
\text { Tradesmen ratios }\end{array}$ & sub-contractor & 0 & 3 & 12 & 30 & 7 & 197 & 75.77 & 5 \\
\hline Defective workmanship & sub-contractor & 0 & 2 & 15 & 27 & 8 & 197 & 75.77 & 6 \\
\hline Low labour skill level & sub-contractor & 0 & 4 & 13 & 26 & 9 & 196 & 75.38 & 7 \\
\hline Constructability problems & $\begin{array}{c}\text { Site } \\
\text { management }\end{array}$ & 0 & 6 & 4 & 39 & 3 & 195 & 75.00 & 8 \\
\hline $\begin{array}{l}\text { Non-compliance with } \\
\text { specification }\end{array}$ & sub-contractor & 0 & 6 & 7 & 33 & 6 & 195 & 75.00 & 9 \\
\hline Change in plans or scope & client-related & 0 & 8 & 5 & 32 & 7 & 194 & 74.62 & 10 \\
\hline
\end{tabular}




\section{Conclusion}

The findings of the study are that four (4) essential causes attribute to rework in infrastructure projects are subcontractor as the predominant causes, followed by design-related, site management and client-related. Most of the respondents expressed that the main attributes to rework causes are mostly attributed to subcontractor factors because a majority of subcontractor's sub-causes are in the top 10 overall rework causes. In each category, there were sub-causes to rework in infrastructure project which are lack of trained supervisors, vague instructions and orders for employees, inadequate supervisor / foreman / tradesmen ratios, defective workmanship, low labour skill level and non-compliance with specification. These are some sub-causes of rework which contribute to the predominant rework causes category which is subcontractor category.

However, the top 10 overall rework causes are communication effectiveness within owners, changes made at client's request, lack of trained supervisors, vague instructions and orders for employees, inadequate Supervisor/ Foreman/ Tradesmen ratios, defective workmanship, low labour skill level, constructability problems, non-compliance with specification and change in plans or scope.

An in-depth study should be carried out to study more on rework causes, potential solutions and as well as the impact of rework on infrastructure projects in Malaysia since studies regarding rework in Malaysia are still very limited.

\section{Acknowledgements}

The authors would like to express their deepest appreciation to all the companies involved in answering the questionnaire survey as well as to Universiti Teknologi MARA Cawangan Pulau Pinang for funding this research and its support.

\section{REFERENCES}

[1] A. R. Ismail, H.M. Aftab \& T. Ahmad, Significant Factors Causing Cost Overrun in Large Construction Projects in Malaysia, Journal of Applied Sciences, Vol. 13, pp. 286293, 2013.

[2] P. E. D. Love, Ph, D., Sc, D. J, Edwards, Ph, D., J. Smith \& $\mathrm{Ph}, \mathrm{D}$., Rework Causation: Emergent Theoretical Insights and Implications for Research, 142(6), 1-9, 2016.

[3] S. Chandrusha \& B. Mehboob, Rework Management in Construction Projects and Comparision with Time and Cost, International Journal of Engineering Science and
Computing, 7(6), 17973-17980, 2016.

[4] S. Abdussalam and S. Karim, Time and Cost Overrun in Construction Projects in Egypt, Coventry university, UK, 2016.

[5] N. Forcada, M. Gangolells, M. Casals, \& M. Macarulla, Factors Affecting Rework Costs in Construction. Journal of Construction Engineering and Management, 143(8), 2017.

[6] A. Shah Ali, A. Smith, M. Pitt, \& C. Choon, Contractors' Perception of Factors contributing to Project Delay: Case Studies of Commercial Projects in Klang Valley, Malaysia. Journal of Design and Built Environment, 7, 43-57, 2010.

[7] P. E. D. Love, \& D. J. Edwards, Determinants of rework in building construction projects. Engineering, Construction and Architectural Management, 11(4), 259-274, 2004.

[8] G. Ye, Z. Jin, B. Xia, \& M. Skitmore, Analyzing causes for reworks in construction projects in China, Journal of Management in Engineering, 31(6), 1-9, 2015.

[9] A. Muwafaq, M. Abdel-Monem, \& K. M. El-Dash, Review study for rework causes in construction industry, Civil Engineering Research Magazine (CERM), 42, No. 1-January 2020, 20 - 35, 2020.

[10] E. K. Simpeh, An Analysis of the Causes and Impact of Rework in Construction Projects, Cape Peninsula University of Technology, 2012.

[11] J. Boon, H. Yap, P. L. Low, \& C. Wang, Rework in Malaysian building construction: impacts, causes and potential solutions, 2017.

[12] P. Ekambaram, REDUCING REWORK TO ENHANCE PROJECT., 2014.

[13] R. Trach, K. Pawluk, \& M. Lendo-siwicka, Causes of Rework in Construction Projects in Ukraine, 2019.

[14] A. Enshassi, M. Sundermeier \& M. A. Zeiter, Factors Contributing to Rework and their Impact on Construction Projects Performance. 8(1), 12-33, 2017.

[15] E. Palaneeswaran, Reducing Rework to Enhance Project. Proceedings of the One Day Seminar on Recent Developments in Project Management in Hong Kong, Hong Kong (10 Pp.)., (c), 1-10, 2006.

[16] S. Chandrusha, \& M. Basha, Rework Management in Construction Projects and Comparison with Time and Cost. 7(6), 13020-13025, 2017.

[17] R. Mcdonald \& G. A. Leed, (n.d.). Root Causes \& Consequential Cost of Rework Root Causes \& Consequential Cost of Rework, Australia, 2017.

[18] A. Nasid, M. Hilmi, \& I. Abd, Successful criteria for large infrastructure projects in Malaysia. 125, 2015.

[19] J. B. H. Yap, I. N. Chow \& K. Shavarebi, Criticality of Construction Industry Problems in Developing Countries: Analyzing Malaysian Projects, Journal of Management in Engineering, 35(5), 2019.

[20] B. G. Hwang \& S. Yang, Rework and schedule performance: A profile of incidence, impact, causes and solutions. Engineering, Construction and Architectural Management, 21(2), 190-205, 2014. 
[21] J.B.H. Yap, P. L. Low \& C. Wang, Rework in Malaysian building construction: impacts, causes and potential solutions. Journal of Engineering, Design and Technology, 15(5), 591-618, 2017.

[22] J. U. Wilson, \& I. A. Odesola, Design-Related Causes of Rework and the Performance of Oil and Gas5 Projects in Nigeria. International Journal of Sustainable Construction Engineering \& Technology, 8(1), 60-76, 2017.
[23] S. F. Ghannadpour, A. Rezahoseini, S. Noori \& M. Bodaghi, Reducing rework and increasing the civil projects quality, through Total Quality Management (TQM), by using the concept of building information modeling (BIM), Journal of Industrial and Systems Engineering, 12(1), 2019.

[24] N. Vilasini, J. Gamage, U. Kahangamage \& N, T., Low Productivity and Related Causative Factors: A Study Based on Sri Lankan Manufacturing Organisations, 411-422, 2012. 